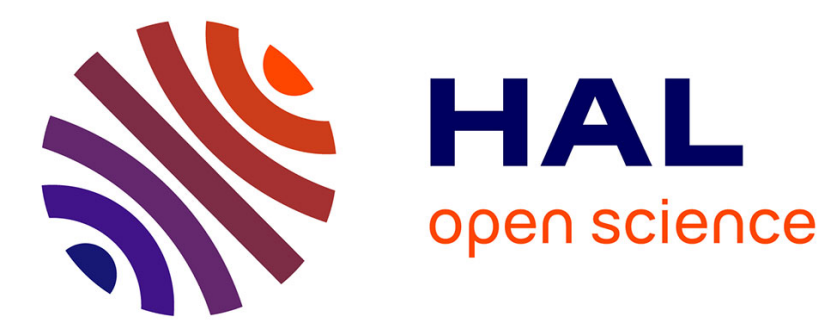

\title{
Friction and wear behaviour and abradability of abradable seal coating
}

Maozhong Yi, Jiawen He, Baiyun Huang, Huijiu Zhou

\section{To cite this version:}

Maozhong Yi, Jiawen He, Baiyun Huang, Huijiu Zhou. Friction and wear behaviour and abradability of abradable seal coating. Wear, 1999, 231 (1), pp.47-53. 10.1016/S0043-1648(99)00093-9 . hal01555292

\section{HAL Id: hal-01555292 \\ https://hal.science/hal-01555292}

Submitted on 7 Jul 2017

HAL is a multi-disciplinary open access archive for the deposit and dissemination of scientific research documents, whether they are published or not. The documents may come from teaching and research institutions in France or abroad, or from public or private research centers.
L'archive ouverte pluridisciplinaire HAL, est destinée au dépôt et à la diffusion de documents scientifiques de niveau recherche, publiés ou non, émanant des établissements d'enseignement et de recherche français ou étrangers, des laboratoires publics ou privés. 


\title{
Friction and wear behaviour and abradability of abradable seal coating
}

\author{
Maozhong Yi ${ }^{a}$, Jiawen He ${ }^{\text {b }}$, Baiyun Huang ${ }^{a}$, Huijiu Zhou ${ }^{\text {b }}$ \\ ${ }^{a}$ State Key Laboratory for Powder Metallurgy, Central South University of Technology, Changsha 410083, China \\ ${ }^{\mathrm{b}}$ State Key Laboratory for Mechanical Behaviour of Metallic Materials, Xi'an Jiaotong University, Xi'an 710049, China
}

\begin{abstract}
The friction and wear behaviour of several kinds of middle temperature abradable seal coatings used in aircraft turbine engine was investigated. Their abradability was evaluated by sliding worn volume. The mechanisms of the sliding wear of the coatings are abrasive wear, adhesive wear and oxidation wear, but the weight of the adhesive wear and abrasive wear is different in different coatings and under different test loads. The results show that the abradability decreases with the increase of the hardness for a given kind of coating. Even if the hardness is close, the abradability is very different in different kinds of coatings. So, only by the hardness can the level of abradability not be not judged and the coating not be chosen and designed. The abradability of M313 type of coating is the best, M310 is close to M601 and M307 with low hardness is fairly good, but M307 with high hardness is the worst.
\end{abstract}

Keywords: Abradable seal coating; Sliding friction and wear; Abradability

\section{Introduction}

Large propulsive force, high efficiency and low fuel consumption are the objectives of the design and manufacture of aircraft turbine engine. So, the clearance between the rotating blades and the casing in the engine should be as small as possible [1]. The gas path sealing has become an important method for this purpose [2]. The thermal sprayed abradable seal coating has been used because of its simple manufacturing processes, easy repair of the components, easy adjustment of its properties and good sealing effectiveness. Also, it can provide thermal barrier for the casing, and reduce the influence of high temperature fuel gas on the casing [2]. The coating is mostly composed of metal phase and self-lubricating non-metal phase with high porosity [3]. It is required that the blades scrape the coating to form a minimum gap. The coating should not only be soft enough to be scraped easily without damaging the blades-good abradability, but also should have high resistance against erosion by the high speed gas flow and solid particles in the gas-good erosion resistance. Therefore, the abradability and erosion resistance are the most important properties of the abradable seal coating. But they are contradictory [4], and the coating should provide a good balance between the abradability and the erosion resistance.

The researchers have paid attention to the study [4] of the powders, spray processes, properties of the coating and the relationship among them. But, the basic researches about the abradability and erosion resistance have not been well-made [5]. The simple methods, such as scratch hardness method, cutting method, and so on, are used for the evaluation of the abradability [6]. The abradability is simply divided into several qualitative grade indexes, such as excellent, good, qualified, and unqualified [6]. That is, there are no standard experimental method and criterion for the evaluation. The hardness of the coating is mostly used as the basis of the coating design, and the criterion for quality control in the preparation of the coating is only the hardness [7]. This paper evaluated the abradability of several kinds of medium temperature abradable seal coatings by sliding wear method and researched their sliding friction and wear behaviour.

\section{Experimental method}

The sprayed powders were METCO 307(75\% Ni $+25 \%$ graphite(G)), METCO 310(57\% Al+8\% Si + 35\% G), METCO $313(40 \% \mathrm{Al}+5.5 \% \mathrm{Si}+45.5 \% \mathrm{G}+9 \%$ organic binder) and METCO 601(40\% polyester $+60 \% \mathrm{Al}-\mathrm{Si}$ al- 
Table 1

Microstructure and hardness of coating specimens

\begin{tabular}{|c|c|c|c|c|c|c|c|c|c|}
\hline Specimen & $\begin{array}{l}\text { Metal } \\
\text { phase }(\%)\end{array}$ & $\begin{array}{l}\text { Non-metal } \\
\text { phase }(\%)\end{array}$ & $\begin{array}{l}\text { Porosity } \\
(\%)\end{array}$ & HR15y & Specimen & $\begin{array}{l}\text { Metal } \\
\text { phase }(\%)\end{array}$ & $\begin{array}{l}\text { Non-metal } \\
\text { phase }(\%)\end{array}$ & $\begin{array}{l}\text { Porosity } \\
(\%)\end{array}$ & HR15y \\
\hline M307-1 & 43.7 & 25.9 & 30.4 & 18 & M313-1 & 74.0 & 18.3 & 7.7 & 74 \\
\hline M307-2 & 46.8 & 26.0 & 27.2 & 20 & M313-2 & 70.1 & 21.8 & 8.1 & 70 \\
\hline M307-3 & 53.6 & 27.3 & 19.1 & 60 & M313-3 & 74.9 & 17.9 & 7.2 & 77 \\
\hline M310-1 & 43.9 & 20.4 & 35.7 & -12 & M601-1 & 29.4 & 69.3 & 1.3 & 51 \\
\hline M310-2 & 62.9 & 14.5 & 7.6 & 28 & M601-2 & 34.1 & 65.2 & 1.7 & 53 \\
\hline
\end{tabular}

loy), which were made by METCO, USA. The sprayed coating specimens were called M307, M310, M313, and M601, respectively. M307 and M310 coatings were sprayed on the blasted surface of the low carbon steel plate by a METCO-6P flame spray system. M313 and M601 coatings was sprayed by a METCO-7MB plasma spray system. The different hardness of the coatings were prepared for one kind of powder by changing spray parameters. The spraying processes, microstructure and properties of all coating specimens were shown in Ref. [8]. The microstructure and the hardness of the specimens are listed in Table 1.

The sliding wear test was carried out on an MM-200 wear testing machine using the form of block-ring. The block specimen was the coating, and the counterpart ring with $36 \mathrm{~mm}$ in diameter and $10 \mathrm{~mm}$ in width was made of AISI152100 steel with HRC63. The sliding speed was
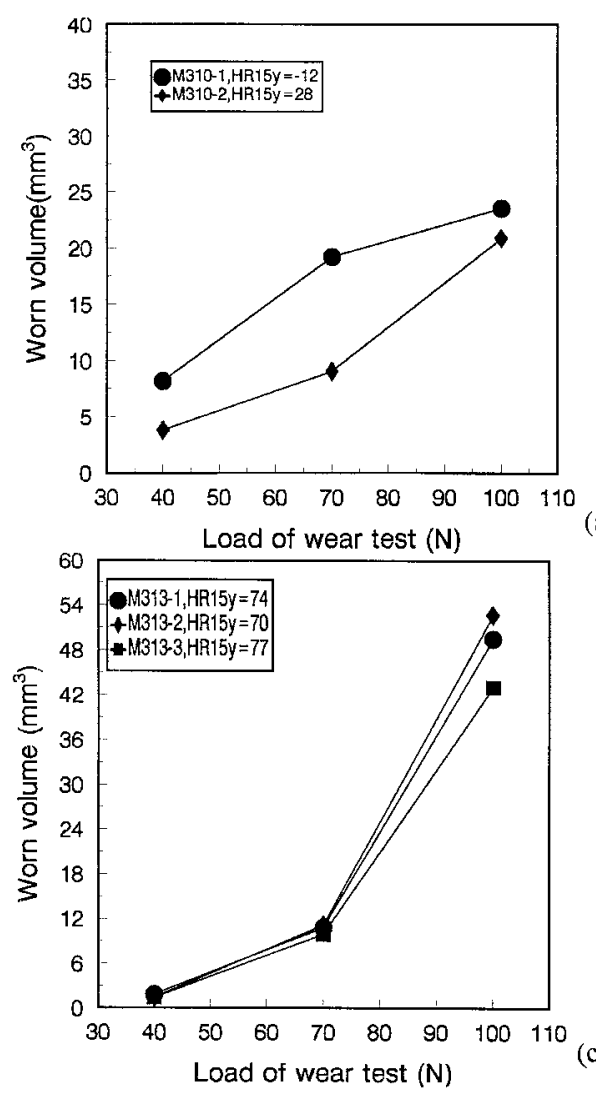

(a)

Fig. 1. Worn volume vs. test load (a) M307, (b) M310, (c) M313, (d) M601.
$0.377 \mathrm{~m} / \mathrm{s}$, and the test loads were 40,70 , and $100 \mathrm{~N}$ for 1 $\mathrm{h}$ without lubricant. The worn volume was calculated by the width and length of the scar, and was used to evaluate the abradability. It is thought that the larger the worn volume, the better the abradability. The surface of worn specimen was analyzed by SEM and EDAX.

\section{Experimental results and discussion}

\subsection{Rules of sliding friction and wear of abradable seal coating}

Fig. 1 shows that the worn volume of four types of the coatings increases with the increase of the test load, which is the same as the common rule of the sliding wear. In general, the worn volume of the coating with high hard-

(b)
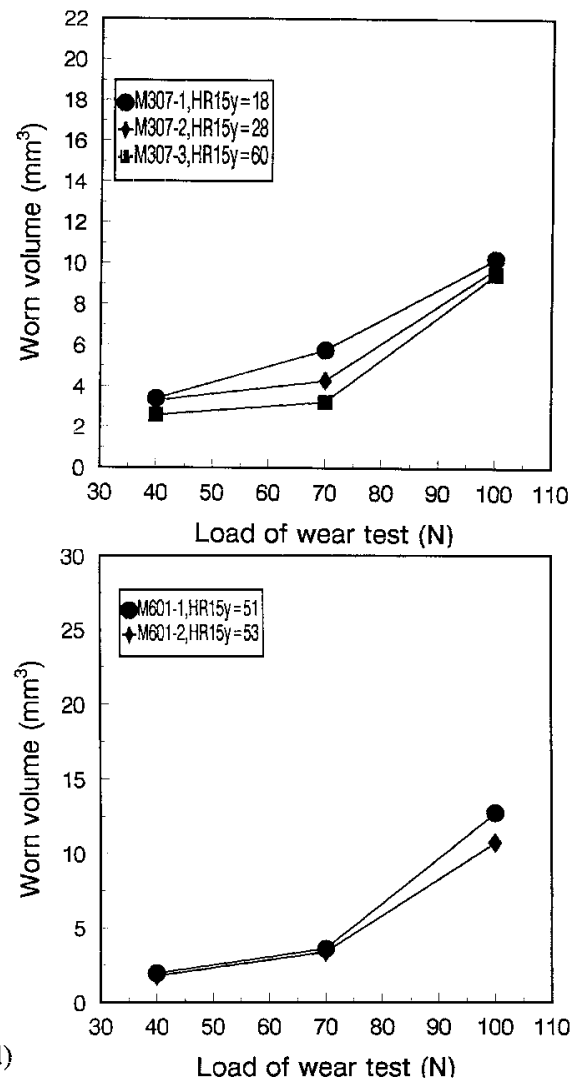


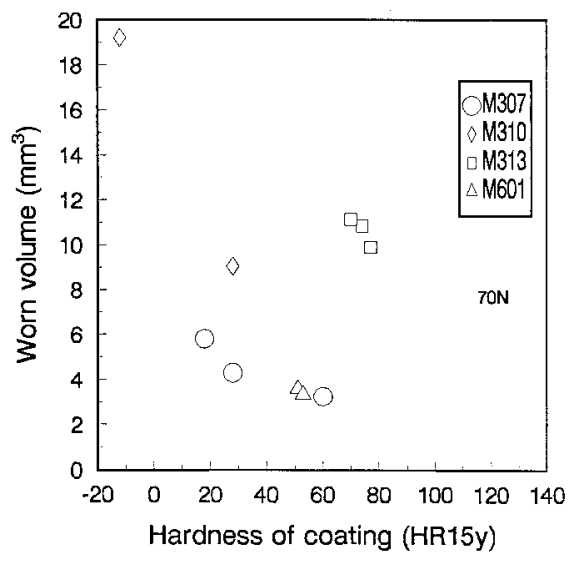

(a)

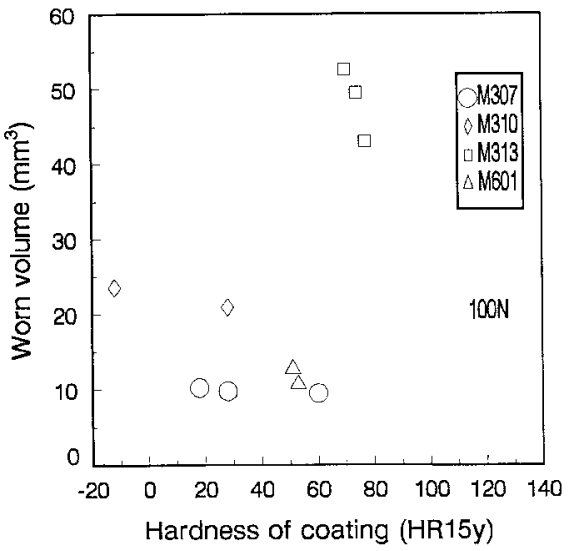

(b)

Fig. 2. Worn volume vs. hardness of coating (a) $70 \mathrm{~N}$, (b) $100 \mathrm{~N}$.

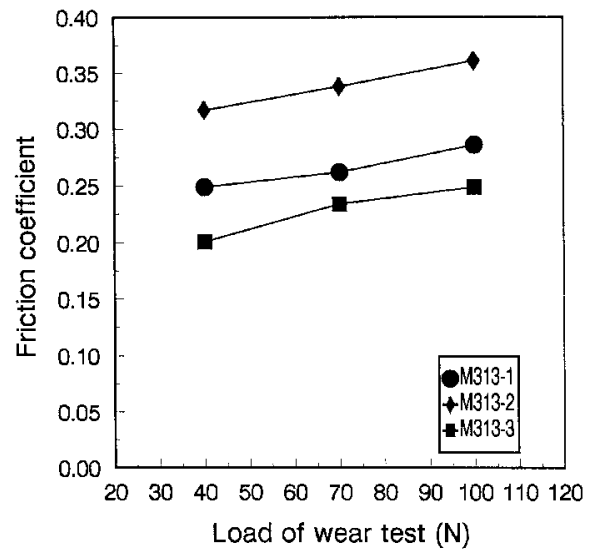

(a) (b)

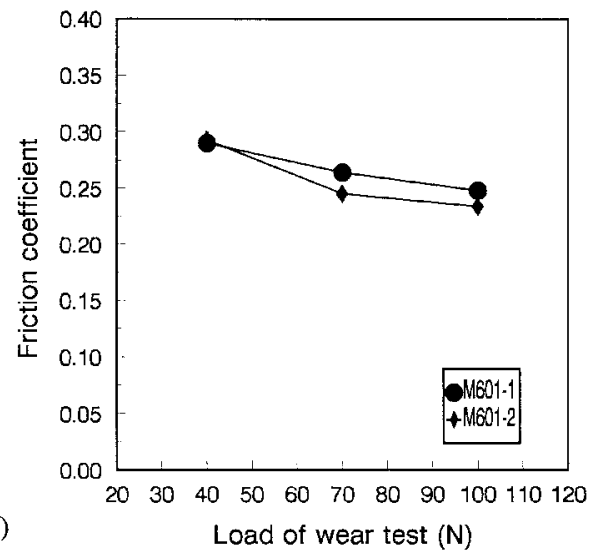

Fig. 3. Friction coefficient vs. test load (a) M313, (b) M601.

ness is small. But, the worn volume is very different in different kinds of coatings under the same experimental conditions. For example, the hardness of M313 is higher than that of M307, but the worn volume of M313 is larger than that of M307 at $100 \mathrm{~N}$ test load. So, it can be seen that the hardness of coating has an obvious influence on the worn volume (abradability), but the abradability does not only rely on it.

Fig. 2 shows the worn volume vs. the hardness of all coating specimens at 70 and $100 \mathrm{~N}$ test load. On the whole, the worn volume or abradability is not obviously related to the hardness of coating. It can be also seen from Figs. 1 and 2 that the abradability of M310 type coating is good at all test load, the abradability of M313 increases remarkably with the increase of the test load and is the best at $100 \mathrm{~N}$ load. It is difficult to explain these results only by the hardness of the coating. The results also indicate that the abradability of the coating is influenced by other factors, such as the composition, microstructure of the coating, and so on. So, the designer cannot choose and design the abradable seal coating, and cannot lay down spray processes only by the hardness.
On the basis of the sliding worn volume, it is obtained that the abradability of M313 type of coating is the best, M310 is close to M601 and M307 with low hardness is fairly good, but M307 with high hardness is the worst. The trend of the results is the same as that of cutting method [8] and energy method [9].

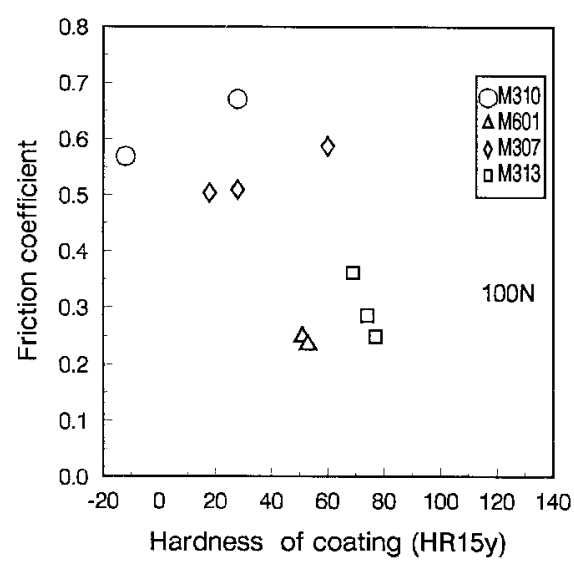

Fig. 4. Friction coefficient vs. hardness of coating. 
Fig. 3 shows the relationship between the friction coefficient of M313 and M601 coatings and the test load. The friction coefficient of M313 increases slightly with the increase of the load, but that of M601 decreases. Fig. 4 shows the friction coefficients of all coating specimens vs. their hardness at $100 \mathrm{~N}$ load, and indicate that the coefficients of M601 and M313 are lower, but those of M307 and M310 are higher.

\subsection{Mechanism analysis of sliding friction and wear of abradable seal coating}

Fig. 5(a) shows the surface morphology of the scar of M307-1 coating after $40 \mathrm{~N}, 1 \mathrm{~h}$ wear. The ploughing ditches produced by abrasive wear on the surface of the metal phase in the coating are clearly exhibited. The metal phase $\mathrm{Ni}$ is dragged into sharp angle-like along the sliding direction by the friction shear stress. This indicates that large plastic deformation occurs on the surface layer of the metal phase. The metal phase separates from the matrix, and the pores form behind the phase. So, the metal phase is the main component to resist against wear and is protruding on the surface of the coating, and the graphite and worn bits lie in the pores or hollow.

The results of EDAX of the worn hits in A zone, the metal phase at B zone and $\mathrm{C}$ zone in Fig. 5(a) are listed in No. 1, 2, 3 of Table 2, respectively. A large amount of Fe, $\mathrm{O}$ in the worn bits (No. 1) indicates that there is some
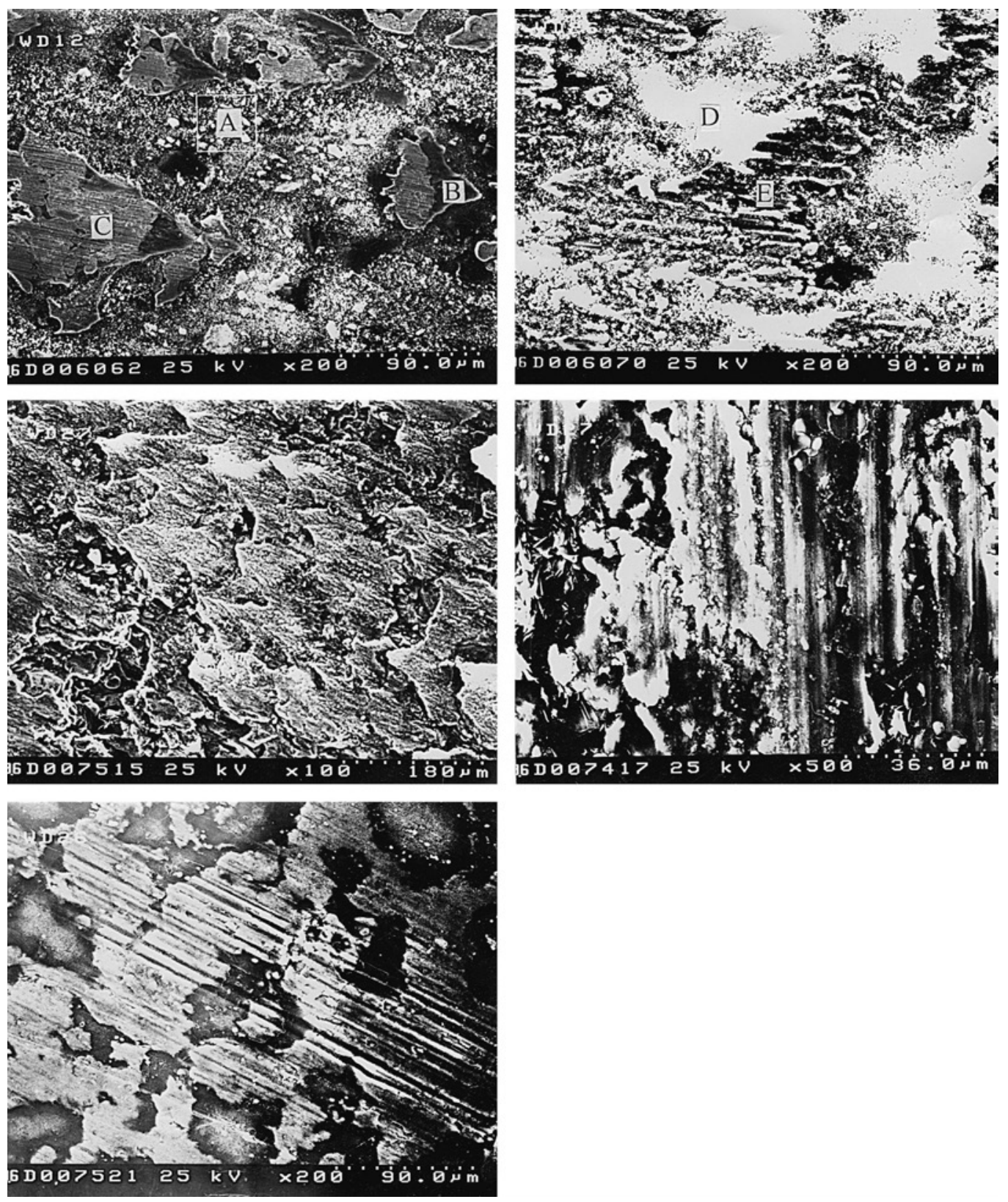

Fig. 5. Surface morphology of worn (a) M307-1, 40 N, (b) M310-2, 70 N (c) M310-2, 100 N, (d) M313-2, 40 N, (e) M601-1, 70 N. 
Table 2

EDAX result of scar and worn bits (wt.\%)

\begin{tabular}{lllllllll}
\hline Specimen & No. & C & \multicolumn{1}{l}{$\mathrm{O}$} & $\mathrm{Fe}$ & $\mathrm{Ni}$ & $\mathrm{Cr}$ & $\mathrm{Al}$ & $\mathrm{Si}$ \\
\hline M307 & 1 & 1.15 & 10.11 & 46.24 & 42.50 & - & - & - \\
& 2 & 0.15 & 12.07 & 60.05 & 26.73 & 1.00 & - & - \\
& 3 & 0.06 & 2.78 & 5.91 & 91.25 & - & - & - \\
M310 & 4 & 0.09 & 24.77 & 38.25 & - & - & 32.26 & 4.64 \\
& 5 & 0.06 & 14.75 & 11.75 & - & - & 68.08 & 5.37 \\
M313 & 6 & 0.214 & 24.05 & 22.05 & - & - & 47.95 & 5.73 \\
& 7 & 15.74 & 6.99 & 20.98 & - & 0.48 & 53.00 & 2.80 \\
M601 & 8 & 0.439 & 23.44 & 3.27 & - & - & 65.39 & 7.46 \\
& 9 & 9.33 & 25.60 & 20.79 & - & 0.47 & 40.53 & 3.28 \\
\hline
\end{tabular}

oxide of the counterpart material. There are more amounts of $\mathrm{Fe}$ and a little $\mathrm{Cr}$ at the $\mathrm{B}$ zone, sharp angle-like which indicates that $\mathrm{Fe}$ and $\mathrm{Cr}$ of the counterpart material adhere to the metal phase in the coating. A smeared layer forms on the adhesive zone (the black region of the sharp anglelike in Fig. 5(a)). At non-sharp angle-like zone, the main composition is $\mathrm{Ni}$, and there is a certain amount of $\mathrm{O}, \mathrm{Fe}$, which indicates that the adhesion is lighter. Thus, the abrasive wear, oxidation wear, and adhesion wear occur in the sliding wear of M307 type of coating.

Fig. 5(b) shows the surface morphology of the scar of M310-2 coating after $70 \mathrm{~N}, 1 \mathrm{~h}$ wear, and a large amount of worn bits and ploughing ditches occur on the scar. The ditches of M310 coating are wider and deeper than that of M307, which indicates that the abrasive wear resistance of $\mathrm{Al}-\mathrm{Si}$ metal phase is worse than that of Ni. The results of EDAX at the white worn bit zone D, and ploughing ditch zone $\mathrm{E}$ in Fig. 5(b) are listed in No. 4, 5 of Table 2, respectively. The worn bits may be $\mathrm{Fe}, \mathrm{Al}, \mathrm{Si}$ and their oxides. Fig. 5(c) shows the surface morphology of M310-2 coating after $100 \mathrm{~N}, 1 \mathrm{~h}$ wear and ultrasonic wave cleaning. The fish-scale-like adhesive wear zone occurs on the worn surface. Because of low melting point of $\mathrm{Al}-\mathrm{Si}$ alloy and high test load, the friction heat makes the surface of $\mathrm{Al}-\mathrm{Si}$ metal phase soften $[10,11]$. The surface layer of the metal phase presents plastic flowing deformation and becomes the scale-like zone.
Fig. 5(d) shows the surface morphology of $40 \mathrm{~N}, 1 \mathrm{~h}$ worn M313-2 coating. The ploughing ditches and scraps beside the ditches can be clearly seen. The curled parts produced by ploughing are milled, deformed, and broken into the scraps. The result (No. 6 in Table 2) of EDAX of the scar, which is a large amount of oxygen and iron, indicates that the adhesive wear and oxidation wear occur.

Fig. 5(e) shows the surface morphology of the scar of M601-1 coating after $1 \mathrm{~h}, 70 \mathrm{~N}$ wear. The ploughing ditches, oxidation wear and adhesive wear also occur on the surface of worn M601 type of coating. The EDAX analysis of the scar (No. 8 in Table 2) indicates that the amount of $\mathrm{Fe}$ is the lowest and the adhesive wear of M601 coating is the lightest in all types of coatings.

\subsection{Discussion on behaviour of friction and wear of abradable seal coating}

The rule of influence of abradable seal coating hardness on worn volume is similar to that of the common wear. The influence embodies the effect of the hardness on the rate of the abrasive wear and the adhesive wear. Suppose that the rule of the wear of the coating accord with the simplified abrasive wear model advanced by Rabinowiez.

$W_{\text {abr }}=\frac{K_{\text {abr }}}{\pi} \frac{L}{H}$

and the adhesive wear model put by Archard:

$W_{\mathrm{adh}}=K_{\mathrm{adh}} \frac{L}{3 \sigma_{\mathrm{s}}}$

where $K_{\text {abr }}$ is the coefficient of abrasive wear, which is related to the properties of abrasive particle, $K_{\text {adh }}$ is the coefficient of adhesive wear, which is related to the material of frictional pairs, $L$ is normal load, $H$ is hardness and $\sigma_{\mathrm{s}}$ is the yield strength of material to be tested. It can be seen from Eqs. (1) and (2) that the rate of both abrasive wear and adhesive wear is in inverse proportion to the hardness under given wear conditions. Eqs. (1) and (2)
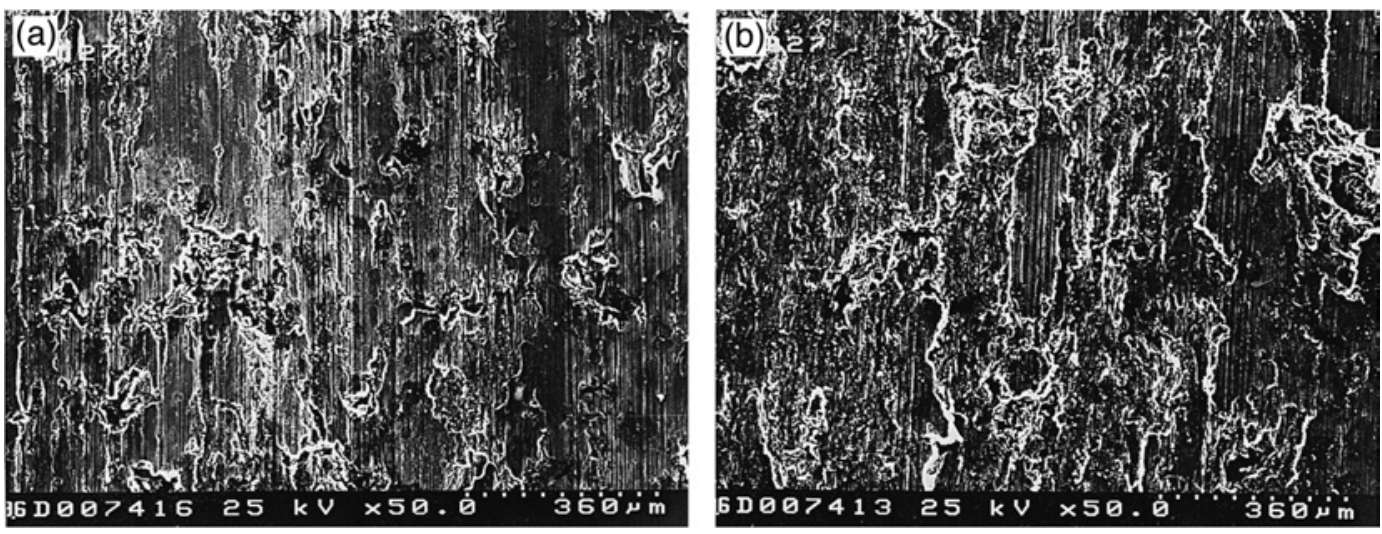

Fig. 6. Surface morphology of worn M313-2 (a) 40 N, (b) 100 N. 

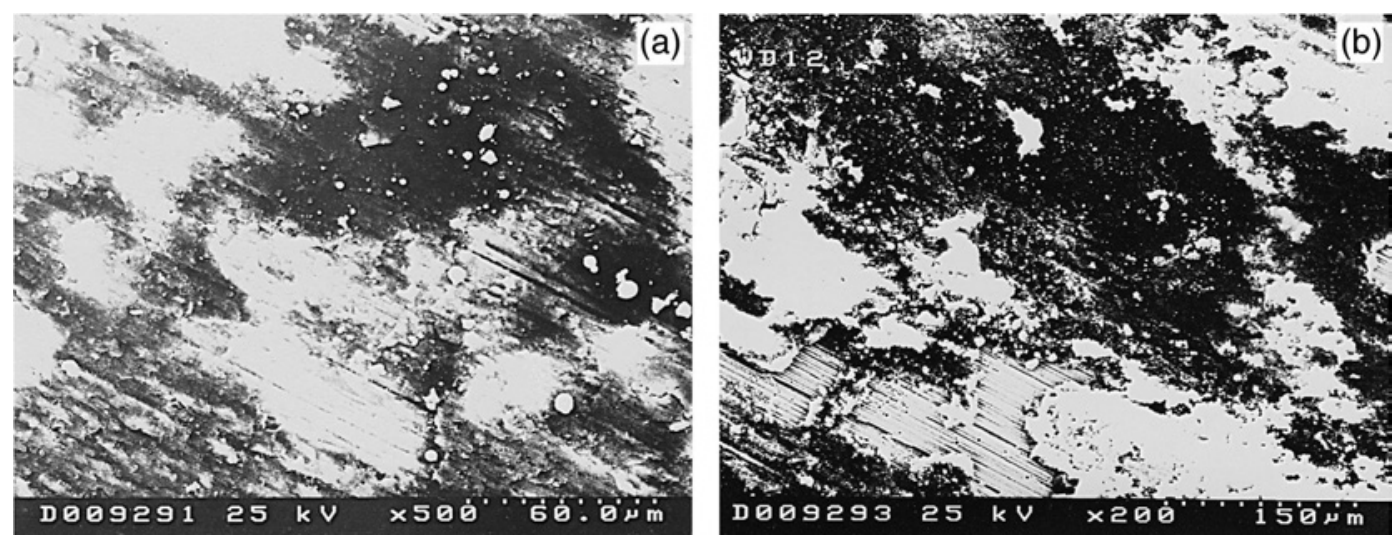

Fig. 7. Surface morphology of worn counterpart with (a) M313-2, (b) M601-1.

only explain qualitatively the effect of the coating hardness on the worn volume.

Because the hardness of Ni metal phase in M307 type of coating (HV $50 \mathrm{~g} \mathrm{130-170)}$ is higher than that of $\mathrm{Al}-\mathrm{Si}$ (HV 50 g 50-90), the width and depth of ploughing ditches on the surface of the coating with Ni metal phase are smaller, the abrasive wear is lighter, but the adhesive wear is more severe. $\mathrm{Fe}$ is close to $\mathrm{Ni}$ in element periodic table, and their inter-dissolubility is good, so the tendency to adhesion is large. Although the content of the graphite in M307 type of coating is high up to $25-30 \mathrm{wt} . \%$, the friction coefficient in Fig. 4 is not low, and the average value is about 0.53 . The reason is that the continuous solid lubricating film of the graphite does not form on the surface of the counterpart, the role of the lubrication of the graphite is not fully played, and there is severe adhesion in the sliding wear of M307.

The metal phase in M313 type of coating endures abrasive wear. But at a higher load $(100 \mathrm{~N})$, the phase bears more severe adhesive wear and the worn volume increases rapidly. The difference in the morphology shown in Fig. 6(a,b) of the scar of M313-2 coating between 40 and $100 \mathrm{~N}$ test load indicates that the adhesive smeared zone is larger and the worn volume is larger at $100 \mathrm{~N}$. The film layer shown in Fig. 7(a) forms on the surface of the counterpart with M313 type of coating in the sliding wear test. The result (No. 7 in Table 2) of EDAX analysis indicates that there are $\mathrm{C}, \mathrm{O}, \mathrm{Al}$, and $\mathrm{Si}$ in the film, which are adhered to the surface of the counterpart from the coatings. The film makes the friction coefficient of M313 type of coating low, and the average value in Fig. 4 is about 0.29 .

The metal phase and non-metal phase in M310 type of coating are similar to that in M313 type of coating, but the amount of graphite is less and the complete graphite lubricating film does not form on the surface of the counterpart. So, the friction coefficient in Fig. 4 is higher, and the average value is 0.61 . In addition, the higher porosity in the coating is also one of the reasons of large worn volume.
A complete film layer shown in Fig. 7(b) formed on the surface of the counterpart with M601 type of coating. The EDAX analysis (No. 9 in Table 2) indicates that the main components in the film are $\mathrm{C}$ and $\mathrm{O}$, which are the elements of the polyester and $\mathrm{Al}$ and $\mathrm{Si}$, which are adhered to the surface of counterpart from the coatings. The film makes the friction coefficient of the coating composed of polyester the lowest and the adhesive wear of M601 coating is slighter than that of M307, M310, and M313. The mean friction coefficient in Fig. 4 is only 0.25 , and the main wear form is abrasive wear. Thus, wear rate of M601 type of coating is at a lower level.

\section{Conclusions}

(1) The abradability of several kinds of middle temperature abradable seal coatings is evaluated by sliding worn volume. The abradability of M313 type of coating is the best, M310 is close to M601 and M307 with low hardness is fairly good, but M307 with high hardness is the worst.

(2) The abradability decreases with the increase of the hardness for a given kind of coating. Even if the hardness is close, the abradability is very different in different kinds of coatings. So, only by the hardness can the level of the abradability not be judged and the coating not be chosen and designed.

(3) The mechanisms of the sliding wear of the coatings are abrasive wear, adhesive wear, and oxidation wear, but the weight of the adhesive wear and abrasive wear is different in different coatings and under different test loads. The weight of the adhesive wear increases with the increase of test load.

\section{Acknowledgements}

The authors are grateful for the support of National Defense Science and Technology Pre-research Foundation of P.R. China. 


\section{References}

[1] J.T. Demasi, Protective coating in the gas turbine engine, Surf. Coat. Technol. 68-69 (1994) 1-9.

[2] E.R. Novinski, The design of thermal sprayed abradable seal coatings for gas turbine engines, Proceedings of 4 th National Thermal Spray Conference, USA, 1991, pp. 451-454.

[3] T. Oka, Basic characteristic of different abradable coatings, Proceedings of International Thermal Spraying Conference, Germany, 1990, pp. $58-67$.

[4] E.R. Novinski, Process parameter impact on the physical properties of an advanced abradable coating, Proceedings of 3rd National Thermal Spray Conference, USA, 1990, pp. 151-157.

[5] M. Yi, Erosion wear of AlSi-graphite and $\mathrm{Ni}$ /graphite abradable seal coating, Trans. Nonferrous Met. Soc. China 8 (2) (1997) 99-102, English letter.

[6] M. Dorfman, A high performance alternative to $\mathrm{NiCrAl}$ /bentonite for gas turbine abradable seals, Proceedings of 13th International Thermal Spray Conference, USA, 1992, pp. 587-594.

[7] T. Chon, Aluminium-silicon/polyester abradable coatings, Proceedings of 3th National Thermal Spray Conference, USA, 1990, pp. 625-630.

[8] M. Yi, Evaluation on adhesive strength of coating layer and characteristics of abradable and anti-wear coating, Doctoral dissertation, Xi'an Jiaotong University, 1996.

[9] X. Zhang, Main characteristic and experimental method study on seal coatings, Master thesis, Xi' an Jiaotong University, 1997.
[10] A.S. Keddy, Wear and seizure of binary Al-Si alloy, Wear 171 (1994) 115-127.

[11] H. Torabin, Wear characteristics of Al-Si alloy, Wear 172 (1994) $49-58$.

Maozhong Yi received his Bachelor's degree in the department of Materials Science and Engineering, Central South University of Technology in China in 1981. In 1988, he obtained his Master degree in the department of Materials Science and Engineering, Xi'an University of Technology. In 1996, he received his PhD from the school of Materials Science and Engineering, Xi' an Jiaotong University. Now he is working the State Key Laboratory for Powder Metallurgy, Central South University of Technology. He is a professor of the university. His research interest is surface engineering of materials.

Jiawen $\mathrm{He}$ is a professor of Xi'an Jiaotong University, his area of research interest is strength and surface engineering of materials.

Baiyun Huang obtained PhD from USA, in 1986, and now is a professor and President of Central South University of Technology. He has worked in the field of powder metallurgy materials science and engineering and published more than 110 research papers in national and international journals.

Huijiu Zhou is a professor of Xi'an Jiaotong University. He is an Academician of Chinese Academy of Science. His research interest is mechanical behaviour of materials. 